Slobodan Radišić ${ }^{2}$, Jožef Kabok ${ }^{1}$, Vladimir Dj. Djaković², Bogdan Kuzmanović ${ }^{2}$ ${ }^{1}$ Provincial Secretariat for Science and Technological Development, Novi Sad, Serbia ${ }^{2}$ University of Novi Sad, Faculty of Technical Sciences, Novi Sad, Serbia

\title{
The Programme Budget Model as a Basis for Measuring the Performance of the Public Sector in Transition Economies
}

UDC: 336.13 .051

DOI: 10.7595/management.fon.2016.0014

\begin{abstract}
Programme budget model is a significant instrument for improving the situation in the public finance system, especially in transition economies. Thus, the process of implementation of reforms and the consolidation of the public sector are essential for the creation of adequate baselines for further sustainable growth and development of transition economies while observing their specificities. Accordingly, the subject of the research is the analysis of the current state of affairs in the process of financial system reforms, that is, public funding with a special focus on the area of budgeting of the higher education in the transition economies of Serbia, Croatia and Hungary. The main objective of the research is determining the performance of the programme budget model in the public sector of the observed transition economies in order to improve public finance management. The research results indicate the adequacy and advantages of using the programme budget model in terms of significant improvement in budgetary performance and results in accordance with the defined programme activities.
\end{abstract}

Keywords: Programme budget model, Public sector, Performance, Transition economies, Performances

\section{Introduction}

Improvement of the budgetary process is part of a more comprehensive public finance management reform, with a focus on determining the priorities and optimized spending for the purpose of stimulating economic growth (Jednak\& Kragulj, 2015) and efficient provision of high quality services by the public administration. Such budgeting enables a better management of public administration performance, a higher responsibility of the budget beneficiaries, establishing stronger connections between the annual budget, setting priority expenses and expenditures and conducting public policies. The aforesaid budget also enables greater transparency in the spending of public funding on the basis of better cost-benefit measuring.

Authorized spending of budgetary funds, or justification of such spending, was not traditionally a priority of governments and, as a rule, was sufficient to prove that the budgetary funds were spent in accordance with the existing legislation, regulations and standards. There was only a compliance with the restraints in terms of using inputs, whereas performance measuring was negligible in such systems. In time, it turned out that, in addition to complying with the legislation, it was also necessary to expand the responsibility to quantitative measuring of the public sector performance and results from using the budgetary funds (Greiling, 2006).

Reforms aimed at introducing a programme budget, and measuring the performance, were initiated in 2005 , and after a year of preparations, the programme budget concept was introduced in 2007, in four pilot ministries, and in the following year in one republic administration as well. It is now quite clear that the process of introducing the programme budget in Serbia needs to proceed with greater determination (Vujović, 2012), with a required expert capacity building, initiating new programme ideas and consolidating programmes in accordance with the budget priorities. 
The subject of the research is the analysis of the current state of affairs in the budget process reforms in Serbia with a special focus on the implementation of the programme budget model as a basis for measuring the performance of the public sector in transition economies, on the example of higher education budgeting. Special attention is therefore given to the fact that the existing legislation regulates the transition to programme budgeting in 2015 . The objective of the research is to analyse, by comparison with the EU member countries, Hungary and Croatia, the significance of programme budget model implementation for the purpose of a more efficient and effective use of public resources in Serbia.

This paper is important from the standpoint of the need to implement the new budget model based on budget programmes and projects in Serbia, especially having in mind that transition has many organizational impacts in the public sector (Todorović, Komazec \& Čudanov, 2013). The paper is therefore important for a large professional and scientific public in transition economies with a special focus on Serbia, and for competent authorities, local autonomies and local government authorities in the area of budgetary funds. After the introductory part, the second chapter of the paper analyses the theoretical background of the programme budget model. The third chapter of the paper gives a research methodology, whereas the fourth chapter presents the structure of this model with an example of implementation of the "Higher Education" Programme in Serbia, Croatia and Hungary. The conclusions explaining the advantages and benefits of the programme budget model implementation are covered in the fifth chapter.

\section{Theorethical Background}

Many authors have dealt with research in a specialized area, which indicates the significance of the specialized area. Namely, Jordan \&Hackbart (1999), Heinrich (2002), Vujovic (2012) carried out research on performances concerning public sector management based on the outcomes. The authors especially emphasized the effectiveness of policies in the given sector, taking into account a greater reliability of the observed public sector. Also, special attention was paid to the effects of an adequate public sector management and the system factors on the outcomes and impacts. The authors conclude that the available administrative data on measuring the activities and outcomes of the observed programme have a significant role in the effectiveness and efficiency of the public sector management system.

Propper \& Deborah (2003) empirically test the indicators of public sector performances, indicating the complexity and challenges of measuring thereof. Namely, the authors focus on analysing the performances of multiple tasks and levels of responsiveness during their implementation. Research is particulary important, as it perceives the state of affairs in the public sector of developed countries (the United States of America and Great Britain) with a special focus on the sectors of education and health care. The authors point out that the efficiency is improved by adequate measuring of performances, but also that improved services of the observed sector pose a special challenge. It is particularly important to pay attention to an adequate achievement of objectives formulated by creators of policies in the subject area.

Curristine, Lonti \& Joumard (2007) analyse and identify key institutional factors which have an impact on the effectiveness and efficiency of the public sector systematically perceiving the budget processes, their performances, as well as hierarchical levels of the implementation thereof. Thereby, the role and use of information is revealed in the process of quantification of the programme outcomes, actual programme activities in the scope of the corresponding budget. The authors particularly analyse the OECD countries due to the current increase in costs and the necessary improvements in the public sector performances on the whole. This research is important as it indicates the complexity of measuring the public sector efficiency, and especially the isolation of effects of individual institutional reforms from other external effects.

Van Thiel \& Leeuw (2002) give an assessment of the public sector performances as a result of the previously implemented administrative reforms, as well as the impacts thereof on the effectiveness of the observed system. The authors state that it is particularly necessary to pay attention to the specificities of the given public sector, and that it is necessary to analyse multiple indicators of performance with an objective to give an adequate assessment of the outcome, both from the short-term and the long-term perspectives. Thereby, due consideration particularly needs to be given to the legitimate interests of all stakeholders concerned and an adequate balance needs to be accordingly established.

Bogt, Henk \& Van Helden (2007) analyse the place, role and importance of consultants-researchers in the process of improving the programme budget performances on the example of Holland. The authors emphasize the importance of research concerning the programme budget implementation in different 
phases. Accordingly, special attention is paid to analysing the contribution of consultants-researchers in terms of the development of innovations in the field of management accounting in the public sector, and their possible institutional role. On the basis of research results, the authors conclude that the improved programme budget format is supported both by the beneficiaries, as well as by the creators of budget information, as the basis of effectiveness and efficiency of the whole public sector.

Taking the aforesaid into account, the actuality of analysing and testing the state of affairs in the public sector, or measuring the performances thereof by means of programme budgeting implementation is beyond any doubt. In the OECD (2007) and the World bank studies (2010) it is emphasized that most countries started with budgeting reforms based on performances relating to the public administration reform, already in the nineties of the past century. In favour of that goes also the fact that programme budgeting was introduced in 26 out of a total of 34 OECD countries and that it took more than ten years to implement the successive reforms which are still going on (Anderson, 2008; Bernhard, Lojtner \& Francreb, 2011). A greater interest in measuring the budget performances in the developing countries and transition countries emerged during the previous century (Olden, 2012; Kraan, Bergvall, Hawkesworth\& Krause, 2006). The World bank studies (2009 - 2010) state that more and more Latin American, Asian and European countries have considered the possibility of introducing and promoting budget performances aiming at showing a positive impact of the programme budgeting and introducing the principle of strategic decision-making in the public sector.

\section{Methodology}

The methodology of the research, applied in this paper, is in the function of the main objective of the research and the establishment of performances of the programme budget model in the public sectors of transition economiessof Serbia, Croatia and Hungary. The theoretical part of the research includes description, classification, explanation and forecast, as well as methods applied in all segments of scientific-research work, for example, the compilation method, classification method, comparison method, etc. The second phase of the research, which assumes the realization of the empirical part, includes the forecast and data processing referring to the indicators of the programme model performance by using the standard statistical methods and analyses. In the aforesaid research phase, secondary data, mostly official statistical reports and data on Serbia, Croatia and Hungary were used.

The methodological framework of examples of the programme budget model structure in the field of higher education assumes the establishment of the purpose of the "Higher education" Programme, programme activities or project by expressing and describing the general social and/or economic effects which should be achieved on a long-term basis. Two types of performance indicators were used in the paper: the indicators of outcomes and the indicators of outputs. Regarding the implementation of the performance indicator, the basic (existing value), as well as the target values had to be determined for the following three years: 2015 , 2016 and 2017 . The basic value of the indicator was determined by using standard statistical sources, for a time sequence of the previous five years, whereas the target values in the mentioned years were determined by the empirical forecast and implementation of the linear trend method. The linear trend method was applied for the reason that in the initial years of implementation of the programme budget model no extreme increase or reduction of the performance indicator is expected, so that the aforesaid statistical method is considered to be adequate for this phase of research. The linear trend method is expressed by an adapted formula (Kovacic 1995):

$$
\mathrm{Y}_{\mathrm{t}}=\mathrm{b}_{0}+\mathrm{b}_{1} \mathrm{t}
$$

with:

$\mathrm{Y}_{\mathrm{t}}$ : Linear trend of performance indicator;

t: Time period expressed in years;

$\mathrm{b}_{0}$ : Time sequence value in matrix;

$b_{1}$ : Linear trend coefficient.

Coefficients $b_{1}$ and $b_{0}$ are calculated by the least square method: 


$$
b_{1}=\frac{\sum Y t-\frac{\left(\sum Y\right)\left(\sum t\right)}{n}}{\sum t^{2}-\frac{\left(\sum t\right)^{2}}{n}}
$$

with:

$\mathrm{b}_{1}$ : Linear trend coefficient;

Y: Time sequence of performance indicator;

$\mathrm{t}$ : Time period expressed in years;

$n$ : Number of observed years (for $t=1,2,3 \ldots n$ with constant pickup $t=1$ ).

$$
\mathrm{b}_{0}=\frac{\sum \mathrm{Y}-\mathrm{b}_{1} \sum \mathrm{t}}{\mathrm{n}}
$$

with:

$\mathrm{b}_{0}$ : Time sequence value in matrix;

Y: Time sequence of performance indicator;

$\mathrm{b}_{1}$ : Linear trend coefficient;

t: Time period expressed in years;

$n$ : Number of observed years (for $t=1,2,3 \ldots n$ with constant pickup $t=1$ ).

Likewise, it was necessary to determine, in the subject research, the amounts of funds required for implementing the "Higher education" Programme in 2015, 2016 and 2017. A calculation of the total annual resources for the said Programme, on the revenue side, was made on the basis of a modified formula method, applied in Serbia (Kabok, 2010), assuming that the revenues for the realization of the Programme are plannned at the necessary level of expenditure in all the observed years.

\section{Results and Discussion}

The Educational sector is taken as an example of the programme budget structure presentation, due to the fact that in many European countries, and especially in the Scandinavian countries with a developed eductional system, such as Denmark, Finland, Norway and Sweden (Bernhard, Lojtner \& Francreb, 2011), but also in other European countries such as Croatia and Hungary, this sector, that is a part of the educational sector - the higher education area, is budgeted according to the direct programme performance. The reason for this is that budgetary financing of university education, in the aforesaid countries, including Serbia, is to a great extent based on the formula founded on the outcomes formula. If, in terms of the results and outcomes in the aforesaid area, there are clear objectives and indicators which can be easily quantified (Curristine, 2005), the programme budget structure of higher education may be adequately perceived and analysed.

\subsection{The Programme Budget in the Area of Higher Education in the Republic of Serbia}

In accordance with the Law on the prescribed obligation of adopting and implementing programme budgeting the programme budget model has been in force in Serbia with full implementation as of the fiscal year 2015 .

\section{The "Higher education" Programme}

The purpose of the Programme: Promotion, development and establishment of an efficient higher education system enabling access to higher education for all persons concerned in order that the system should provide good quality higher education, and that it be efficient and competent.

The objectives of the Programme implementation in the period 2015-2017 and indicators of success which will be used to measure the achievement of objectives:

Objective1: Reduction of unemployment of persons with a University degree so that the number of unemployed persons who graduated in 2015 is lower than $0.5 \%$ out of the total number of unemployed. 
Table 1: Outcome indicators

\begin{tabular}{|l|l|c|c|c|}
\hline Indicator 1 Basic value & 2015 & 2016 & 2017 \\
\hline $\begin{array}{l}\text { Percentage of unemployed } \\
\text { persons with a University } \\
\text { degree out of the total number } \\
\text { of unemployed as of 31st }\end{array}$ & & & & \\
December.
\end{tabular}

Source: Statistical Yearbook of the Republic of Serbia (2014) and the authors' calculations

Objective 2: Higher quality of studies at state universities

Table 2: Output indicators

\begin{tabular}{|c|c|c|c|c|}
\hline Indicator 1 & Basic value & 2015 & 2016 & 2017 \\
\hline $\begin{array}{l}\text { Yearly number of graduated } \\
\text { students }\end{array}$ & 47,797 & 48,500 & 48,800 & 48,850 \\
\hline
\end{tabular}

Source: Statistical Yearbook of the Republic of Serbia (2014) and the authors' calculations

\subsection{Programme Budget in the Area of Higher Education in Croatia}

Croatia, in contrast to Serbia, has made considerable progress in terms of programme budget model and strategic planning implementation. Within the framework of the applied budgeting model, two types of budget performance indicators may generally be recognized:

- Output indicators, defined as a measurable level of production of goods and services from the planned activities defined on the level of ministries;

- Output indicators, defined as measurable achievement of strategic objectives that must be based on clearly defined, unambiguous and generally comprehensible concepts in order to enable monitoring and assessment of the achievements thereof.

\section{The "Higher education" Programme}

Programme purpose: Stimulating high quality work and University management for the purpose of strengthening global competitivenes on the regional and international levels, as well as increasing the number of highly educated persons in Croatia.

The objectives of the Programme implementation in the period 2015-2017 and indicators of success which will be used to measure the achievement of objectives:

Objective 1: Promotion of the quality, management and higher education funding system.

Table 3: Performance indicators

\begin{tabular}{|c|c|c|c|c|}
\hline Indicator 1 & Basic value & 2015 & 2016 & 2017 \\
\hline $\begin{array}{l}\text { State universities, faculties and } \\
\text { schools for higher education } \\
\text { which introduced internal } \\
\text { management mechanisms for } \\
\text { conducting the "aggregate } \\
\text { amount" funding method }\end{array}$ & 1 & 16 & 18 & 20 \\
\hline
\end{tabular}

Source: State Calculator of the Republic of Croatia for 2015 and projections for 2016 and 2017 
Objective 2: Develop quality insurance on all levels of pedagogy and education.

Table 4: Performance indicators

\begin{tabular}{|l|c|c|c|c|}
\hline Indicator 1 & Basic value & 2015 & 2016 & 2017 \\
\hline $\begin{array}{l}\text { Increased share of higher } \\
\text { education institutions which are }\end{array}$ & & & & \\
the basis of a functional internal & 29 & 9 & 18 & 27 \\
$\begin{array}{l}\text { system of quality insurance } \\
\text { subject to an external review } \\
\text { procedure }\end{array}$ & & & & \\
\hline
\end{tabular}

Source: State Calculator of the Republic of Croatia for 2015 and projections for 2016 and 2017

\subsection{Programme Budget in the Area of Higher Education in Hungary}

In Hungary, a specific programme budget model harmonized with the development strategies and objectives of an EU member country is in force (Kraan, Bergvall, Hawkesworth\& Krause, 2007). The Budget Law of the Republic of Hungary for the year 2015 does not give indicators of results for monitoring the budget fund realization, but gives detailed information and explains the objectives whose implementation is planned by means of budget funding. Likewise, the aforesaid 2015 Law gives a budget projection for the following two fiscal years, 2016 and 2017, which is the practice in programme budgets and which is done in the state budgets of Serbia and Croatia for 2015.

\section{The "Higher education" Programme}

The authorized Ministry of higher education in Hungary is the Ministry for Human Resources within whose budget resources were planned for an unhindered functioning and development of higher education. The objectives were intended to be achieved by the implementation of budget funds in Hungary, in 2015, in the area of higher education, refer to higher competitiveness in this scientific and educational field, realization of labour market requirements for highly professional staff, incentives for the development of technical sciences and the IT sector, changes in the study programme structure for the purpose of ensuring a higher quality of education, as well as providing a return on invested social funds to higher education. Other than that, higher education in Hungary needs to provide implementation of higher education activities within the network of higher education institutions in Hungary, international cooperation, development of scientificresearch activities and innovations, talents, as well as faster economic and technological development of the country. No indicators of results for the "Higher education" Programme are given nor is it defined how the achievement of planned budget objectives in this area will be measured and perceived.

\subsection{Comparative Analysis of Planned Resources for the "Higher education" Programme in the Republics of Serbia, Croatia and Hungary}

Implementation of the "Higher education" Programme assumes yearly planning of resources intended for achieving programme activities and projects of the aforesaid Programme in Croatia and Hungary, which are EU members, whereas Serbia is a candidate member. Planning of resources in 2015, 2016 and 2017 for this Programme in the above countries, is included in Table 5: 
Table 5: Example of planned amounts of resources for the "Higher education" Programme and share of resources in the aggregate budget for 2015, 2016 and 2017 in Serbia, Croatia and Hungary

\begin{tabular}{|c|c|c|c|c|}
\hline No. & State/percentage share & 2015 & 2016 & 2017 \\
\hline 1. & Serbia (EUR) & $341,350,000$ & $342,960,000$ & $345,850,000$ \\
\hline 1.1 . & $\begin{array}{l}\text { Percentage of share in the } \\
\text { budget }(\%)\end{array}$ & 3.6 & 3.5 & 3.4 \\
\hline 2. & Croatia (EUR) & $507,340,000$ & $377,790,000$ & $367,380,000$ \\
\hline 2.1 . & $\begin{array}{l}\text { Percentage of share in the } \\
\text { budget(\%) }\end{array}$ & 3.0 & 2.2 & 2.2 \\
\hline 3. & Hungary (EUR) & $1,549,300,000$ & $1,467,900,000$ & $1,470,700,000$ \\
\hline 3.1 & $\begin{array}{l}\text { Percentage of share in the } \\
\text { budget }(\%)\end{array}$ & 3.3 & 3.1 & 3.0 \\
\hline
\end{tabular}

Source: Budget Law of the Republic of Serbia for 2015, State Calculator of the Republic of Croatia for 2015 and projections for 2016 and 2017 and Draft Budget Law of Hungary for 2015 with explanations

It may be concluded from the presented table that the greatest amount of resources is set aside in Hungary for activities and development of higher education in the three analysed budget years. Funding of higher education in Hungary by the founders of institutions (government) is regulated according to the formula model, assuming that the resources set aside for higher education activities are planned in the budget on the basis of the mathematical formula (Jongbloed, 2003). The basic funding criterion in the formula is determined on the basis of inputs, that is, number of accepted budget students for whose training costs complete funding is provided from the budget, in contrast to self-financing students who have to cover their university or higher education fees by themselves.

Significant resources for higher education funding, according to the programme budget model in the analysed three fiscal years, are also set aside in Croatia. According to the above funding model in Croatia, the aggregate resources are allocated to universities according to the "aggregate amount" model. The "aggregate amount" model assumes that total funds are allocated to higher education institutions, and not according to the prescribed budget items. It may therefore be concluded that the higher education financing model applied in Croatia is directed towards the integration of universities, but not towards either a wider or a financial autonomy of higher education institutions (Kabok,2013).

In Serbia, in comparison with the previously analysed two EU countries, the least amount of funds was set aside, on the basis of the programme budget model, for financing higher education in the analysed three fiscal years. The higher education funding model based on a formula with dominant input criteria in allocating funds to institutions from public sources is in use. The specificity of higher education funding in Serbia is that faculties, as constituents of the university, are independent legal persons with independent financial operations and current account within the consolidated treasury. In accordance therewith the budget funds are allocated directly to faculties, and not through the integrated university which is the case in most European countries (Kabok, 2010).

With respect to the structure of planned resources for higher education, a similar structural share of funds intended for financing higher education is acknowledged in the total state budget of all three analysed countries. The aforesaid information is indicative for the reason that it indicates that the total volume of the state budget is important for financing higher education, and that more developed countries have a comparative advantage in that respect. 
Conclusion

On the basis of the research results, and with a special focus on the area of higher education budgeting, it may be concluded that the introduction of the programme budget model should improve the budget performance and results set by the programme budget model. Namely, there is an undeniable need for a full implementation of the above budget model in Serbia aiming at increasing the responsibility in the management of state affairs, for the purpose of improving the management of public finances. The formal requirements in terms of compliance of the budget and fiscal policies with the EU standards are also an important initiator of reforms in the area of public finances in Serbia, assuming the implementation of the programme budget model and introduction of performance measuring. Comparative analysis using the budgeting models, from the particular aspect of higher education budgeting in the two neighbouring EU member countries, Croatia and Hungary, only confirms this statement.

The courses of further research in this area assume a continuous perspective of the results and outputs of the programme budget model in Serbia, as well as in the regional countries, by measuring the defined indicators of outputs, outcomes and performance with special reference to the specificities of transition economies.

\section{REFERENCES}

[1] Anderson, B. (2008, June). Performance Budgeting: A Users Guide. International Conference Budgeting, Mexico City, Mexico.

[2] Bernhard, R., Lojtner, J.,\& Francreb, D. (2011). Sector Programme Public Finance, Administrative Reform, Transparency Initiatives, Deutche Gesellschaft Internationale Zusammenarbeit (GIZ) GmbH, Eschborn.

[3] Bogt,T., Henk J., \& Jan van Helden, G. (2011). The role of consultant-researchers in the design and implementation process of a programme budget in a local government organization. Management Accounting Research, 22 (1), 56-64.

[4] Budget law of the Republic of Serbia for 2015 ("Official Gazette RoS“, No.142/14).

[5] Central budget of Hungary for 2015, Official Gazette of Hungary No.184 f 29th December 2014, 2014http://kozlonyok.hu/nkonline/MKPDF/hiteles/MK14184.pdf

[6] Curristine, T. (2005). Performance Information in the Budget Process: Results of the OECD 2005 Questionnaire. OECD Journal on Budgeting, 5(2), ISSN 1608-7143, http://www.oecd.org/gov/budgeting/43480959.pdf

[7] Curristine, T., Lonti, Z.,\& Joumard, I. (2007). Improving Public Sector Efficiency.OECD Journal on Budgeting, 7(1), 1-41.

[8] Greiling, D. (2006). Performance measurement: a remedy for increasing the efficiency of public services?, International Journal of Productivity and Performance Management, 55 (6), 448 - 465.

[9] Heinrich, C. J. (2002). "Outcomes-based performance management in the public sector: implications for government accountability and effectiveness." Public Administration Review, 62(6), 712-725.

[10] Hungarian government, Draft law on the budget of Hungary for 2015 with explanation, Budapest, October, 2014

[11] Jednak, S., \& Kragulj, D.(2015). Achieving Sustainable Development and Knowlwd-Based Economy in Serbia. Management, 75, 1-12. doi:10.7595/management.fon.2015.0015

[12] Jongbloed, B. (2003). Institutional Funding and Institutional Change, In File, J. and L. Goedegebuure (Eds) Real-Time Systems. Reflections on higher education in the Czech Republic, Hungary, Poland and Slovenia. Vutium Press, Brno,115-146.

[13] Jordan, M.,\& Hackbart, M., (1999). Performance Budgeting and Performance Funding in the States: A States Assessment. Public Budgeting and Finance, 19(1), 68-99.

[14] Kabok, . (2010). Models of investing in higher education. Annals of the Faculty of Economics in Subotica, 24, 155-168.

[15] Kabok, J. (2013). Analysis of Higher Education Efficiency in Serbia,Management, 67, 47-54, doi:10.7595/management.fon.2013.0008.

[16] Kovačić, Z. (1995). Analysis of time series, Faculty of Economics, University of Belgrade, Belgrade.

[17] Kraan, D.J., Bergvall, D., Hawkesworth, I.,\& Krause, P. (2006). Budgeting in Croatia. OECD Journal on Budgeting, 5(4), 1-60. 
[18] Kraan, D.J., Bergvall, D., Hawkesworth, I.,\& Krause, P. (2007). Budgeting in Hungary. OECD Journal on Budgeting, 6(3), 1-61.

[19] OECD (2007). Performance Budgeting in OECD countries, OECD Publishing.

[20] Olden, B. (2012). Programme budgeting according to performance - experience of Southeast Europe: Their role in the fiscal consolidation process, PEMPAL meeting, Bohinj, Slovenia.

[21] Propper, C.,\& Deborah, W. (2003). The use and usefulness of performance measures in the public sector.Oxford review of economic policy, 19(2), 250-267.

[22] State Calculator of the Republic of Croatia for 2015 and projections for 2016 and 2017, Croatian Parliament, $2^{\text {nd }}$ December 2014,http://www.mfin.hr/hr/state (state- calculator-2015).

[23] Statistical Office of the Republic of Serbia, Statistical Yearbook of Serbia, Belgrade, 2014.

[24] Todorović, I., Komazec, S., \& Čudanov, M. (2013). Different successful patterns for implementing holding model in public sector. Business Systems Research,4(2), 58-67.

[25] Van Thiel, S., \& Leeuw, F., L. (2002). The performance paradox in the public sector.Public Performance \& Management Review, 25(3), 267-281.

[26] Vujović, D. (2012). Study on the efficient use of performance indicators in the process of drawing up the budget and plans in the public sector - Creation of performance indicators for the purpose of improving the programme budget performance in Serbia, USAID Project for better business conditions, Belgrade.

[27] World bank (2009). Performance - Based Budgeting and Medium - Term Expedinture Frameworks in Emerging Europe, Editor Team: Kasek, L., \& Webber, D.

[28] World bank, (2010). Results, Performance Budgeting and Trust in Goverment, Editor Team: Arizti, P., Brumby, J., Manning, N.,\&. Senderowitsch, R.

Receieved: May 2016. Accepted: June 2016.

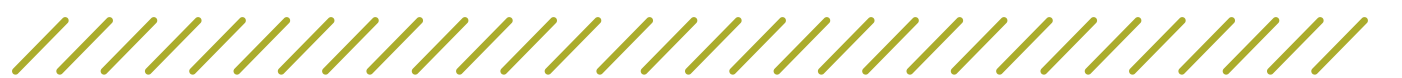 \\ Slobodan Radisic \\ University of Novi Sad, Faculty of Technical Sciences, Novi Sad, Serbia}

About the Author

Dr Slobodan Radisic, PhD is a docent at the Faculty of Technical Sciences in Novi Sad, in the Production systems, organization and management areas. He has attained the title of PhD of economics at the Faculty of Economics of the University of Niš and his

field of research focused on the models of managing business risk in terms of business optimization. His research is focused on the revision process, accounting and public

finance. He is also known as an author and co-author of the multiple scientific research in national and international magazines. The field area for this research is social and national capital privatization, revision and controlling in public services, management accounting and financial management. Slobodan is also a lecturer at the Faculty of economics and Engineering in Novi Sad at Business Economy and Finance study programme.

\section{Dr Jožef Kabok Provincial Secretariat for Higher Education and Scientific Research, Novi Sad Jozef.Kabok@vojvodina.gov.rs}

Dr Jožef Kabok is employed in the Provincial Secretariat for Higher Education and Scientific Research of the Autonomous Province of Vojvodina. He successfully defended his Master's thesis in the field of management and business at the Faculty of Economics in Subotica, University of Novi Sad, and his $\mathrm{PhD}$ in the field of engineering management at the Faculty of Technical Sciences in Novi Sad, University of Novi Sad. He has published papers in the areas of financing and management of higher education. He

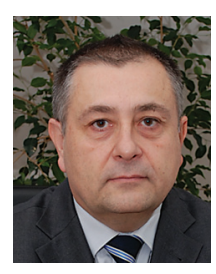
lives in Novi Sad. 


\section{Vladimir Djaković \\ University of Novi Sad, Faculty of Technical Sciences, Novi Sad, Serbia}

Vladimir Djaković was born at Novi Sad on $1^{\text {st }}$ February, 1980. He did his Ph.D. thesis in 2013 in the field of Investment Management at the University of Novi Sad, Faculty of Technical Sciences. Assistant Professor Djakovic's field of interest includes the following: Investment management, Financial management, Risk management and Portfolio management. His research focuses on the investment optimization processes using modern risk management investment tools. Special emphasises in his research is placed on transitional economies and the possibilities of using modern investment optimisation tools on these markets. He has taught courses at all levels (B.Sc., M.Sc. and Ph.D.).

\section{Bogdan Kuzmanovic \\ University of Novi Sad, Faculty of Technical Sciences, Novi Sad, Serbia}

Dr Bogdan Kuzmanovic has been employed at the Faculty of Technical Sciences in Novi Sad, as an assistant professor in the field of insurance, prevention engineering and risk management at the undergraduate, master's and doctoral studies.

$\mathrm{He}$ has a several year experience in industry. For more than 20 years he worked in the insurance company DDOR Novi Sad where he was the general manager. Now, in addition to his engagement at the Faculty, he is engaged in Transnafta as a CFO. $\mathrm{He}$ is an author and co-author of several papers in the field of organization, management and risk management .
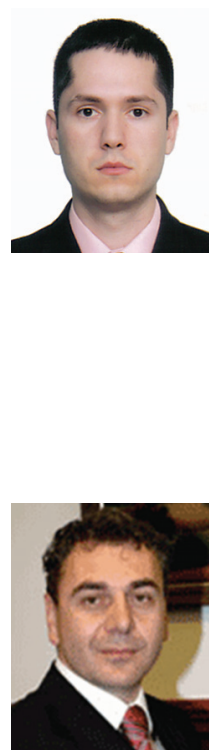